\title{
THE CANONICAL ANALYSIS APPLIED TO THE TAXONOMY AND EVOLUTION OF THE GENUS TIMARCHA Latr. (Coleoptera, Chrysomelidae)
}

Spain.

E. Petitpierre. Depto. Genética. Fac. Biología Univ. Barcelona,

and

C.M. Cuadras. Seminario Matemático. Univ. Barcelona, Spain.

\section{INTRODUCTION}

The beetles of the genus Timarcha belong to a group which is perfectly separated from the remaining genera of the Chrysomelinae subfamily by some morphological traits but principally by their male genitalia (Chen, 1934; Jolivet, 1950; lablokoff-Khnzorian, 1966). On the other hand, the systematics within the Timarcha has been developed with very different criteria because of the diverse values given to multiple forms and even individual aberrations. For this reason all the authors have recognized the systematics of Timarcha as very confused and problematic.

The difficulties faced in the taxonomy of Timarcha derive from the fact that these beetles have a strong tendency to give rise to local races and endemic species and show a high level of individual variation. Thus, the number of the described «species» (Fairmaire and Allard 1873; Fairmaire, 1884; Bechyné, 1948) may be considered as innaccurate and undoubtedly exaggerated. Recent partial revisions, based solely upon morphological characters, have proved the existance of many synonyms (Kocher, 1951; 1956; Jeanne, 1965), but the taxonomic status of several forms remain unsolved.

To establish a true biological species in a problematic group is a task which often requires other studies in addition to those which are purely morphological (Mayr, 1963, 1969). In our opinion, the «species» problem in Timarcha will only be clarified by the fusion of several lines of research, on large population samples observed and analyzed both in the open and in the laboratory. 
In an attempt to carry out this large program, we did chromosome analyses (Petitpierre, 1970 a; 1973; 1976), a study of the variation in one morphological trait and in male genitalia (Petitpierre, 1970 b), ecological observations (Jolivet and Petitpierre, 1973), and some biochemical and serological tests (Petitpierre, 1973). These papers have emphasized the uniqueness of some species and the close interrelationships between a cluster of forms which were finally considered of infraspecific rank.

The present paper deals with the application of a multivariate statistical analysis, the Canonical Analysis, to improve our knowledge on the taxonomy and phylogenetic interrelationships in Timarcha. It represents an enlargement and a full development of the results briefly described elsewhere (Petitpierre, 1973).

The usefulness of this method with regard to the systematics has been proven by several recent papers (see Prunus and Lefébvre, 1971; Louis and Lefébvre, 1971; Rostron, 1972). Nevertheless, some authors have recently used biometric methods for the taxonomy of Timarcha. Stockmann (1966) achieved the separation of some groups of species but failed to discriminate between «species» included in the same group. Minelli and Vittorelli (1976) demonstrated a rassenkreiss for many forms classified into the $T$. tenebricosa group of Bechyné (1948), and concluded that they pertain to only one species.

\section{MATERIAL AND METHOD}

Thirty-two population samples of males and twenty-nine of females, coming from Spain (Sp.), France (Fr.), Italy (It.), and Morocco (Mo.), were subjected to Canonical Analysis. Most of these samples were compound of 40 individuals, caught at the same locality in a period from 1966 to 1972 . The taxa analyzed, their geographical source, and the size of the samples, are given in Table I. All these taxa belong to Timarcha s. str. or to the ancient Timarchostoma subgenus, since representatives of the Americanotimarcha and Metallotimarcha subgenera were not available. The map represented in fig. 1 indicate the geographical location of these samples. In several taxa more than one population sample was submitted to the analysis.

Three measurements of the pronotum and two of the elytra were taken of each individual of both sexes with the aid of a fine calipers. These measurements were expresed in units of $0.1 \mathrm{~mm}$. In addition, three measurements of the 2 nd. tarsomere were taken in each male individual by an ocular micrometer. A detailed representation of the eight characters measured is shown in fig. 2. These characters have been used in the work of Stockmann (1966) and most of them are 


\section{TABLE I}

\begin{tabular}{|c|c|c|c|c|}
\hline No. & Taxa & size of & do & $\begin{array}{l}\text { des } \\
\text { ㅇㅇ }\end{array}$ \\
\hline 1 & T.sinuatocollls Fairm. & Campellas (Pyr Gerona, Sp.) & 40 & 40 \\
\hline 2 & Id. & Planolas (Pyr. Gerona, Sp.) & 40 & 40 \\
\hline 3 & $\begin{array}{l}\text { T.indet.sp. } \\
\text { (Grup T.monticola) }\end{array}$ & Vall de பauset (Pyr. Huesca, Sp.) & 40 & 20 \\
\hline 4 & T.monserratensis Bech & Collformic (Barcelona, Sp.) & 40 & 40 \\
\hline 5 & id. & Collsuspina (Barcelona, Sp.) & 40 & 40 \\
\hline 6 & T.catalaunensis Fairm. & La Garriga (Barcelona, Sp.) & 40 & 40 \\
\hline 7 & T.affinis Laboiss. & Tibidabo (Barcelona, Sp.) & 40 & 38 \\
\hline 8 & Id. & Garraf (Barcelona, Sp.) & 40 & 40 \\
\hline 9 & id. & S. Pere de Roda (Gerona, Sp.) & 40 & 40 \\
\hline 10 & T.recticollis Fairm. & Port de la Bonaigua (Pyr.Lérida, Sp.) & 40 & 40 \\
\hline 11 & T.strangulata Fairm. & id. & 40 & 40 \\
\hline 12 & T.pereal Fairm. & Villanubla (Valladolid, Sp.) & 40 & 40 \\
\hline 13 & T.geniculata Germ. & Pto. de Aliva (Santander, Sp.) & 40 & 40 \\
\hline 14 & T.marhima Perr. & Ondres-Plage (Landes, Fr.) & 40 & - \\
\hline 15 & T.monticola Fairm. & Gourette (Pyr. Atl.,Fr.) & 17 & - \\
\hline 16 & T.cyanescens Fairm. & Cap S. Martin (Pyr.Atl., Fr.) & 28 & 10 \\
\hline 17 & T. fallax Pérez & Alió (Tarragona, Sp.) & 40 & 40 \\
\hline 18 & Id. & Port d'Ager (Lérida, Sp.) & 40 & 40 \\
\hline 19 & Id. & Aldea (Tarragona, Sp.) & 40 & 40 \\
\hline 20 & Id. & Paterna (Valencia, Sp.) & 14 & - \\
\hline 21 & T.Intermedla H.S. & Isla de Tabarca (Alicante, Sp.) & 40 & 40 \\
\hline 22 & T.balearica Gory & Mahón (Baleares, Sp.) & 24 & 15 \\
\hline 23 & Tinicaensts Villa & Roccacainola (Naples, It.) & 15 & 13 \\
\hline 24 & T.tenebricosa F. & Planolas (Pyr. Gerona, Sp. & 36 & 36 \\
\hline 25 & Id. & Vall de Llauset (Pyr. Huesca, Sp. & 10 & 21 \\
\hline 26 & T.espaunoli Bech & Isla de Tabarca (Alicante, Sp.) & 40 & 40 \\
\hline 27 & T.ventricosa Wse. & El-Jadida (Western Mo.) & 16 & 18 \\
\hline 28 & T.Intersthialis Tairm. & Canet-Plage (Pyr.Or., Fr.) & 22 & 17 \\
\hline 29 & T.insparsa Rosenh. & Veleta $2,500-3,000 \mathrm{~m}$. (Granada) & 24 & 31 \\
\hline 30 & T.lugens Aosenh. & id. & 40 & 40 \\
\hline 31 & T.rugosa L. & Melilla (Eastern Mo.) & 18 & 24 \\
\hline 32 & T.plmelloides H.S. & Palermo (Sicily, It:) & 40 & 40 \\
\hline
\end{tabular}


FIG. 1

Geographic distribution of the sampled populations in Timarcha. The two Italian populations are not represented in this map.

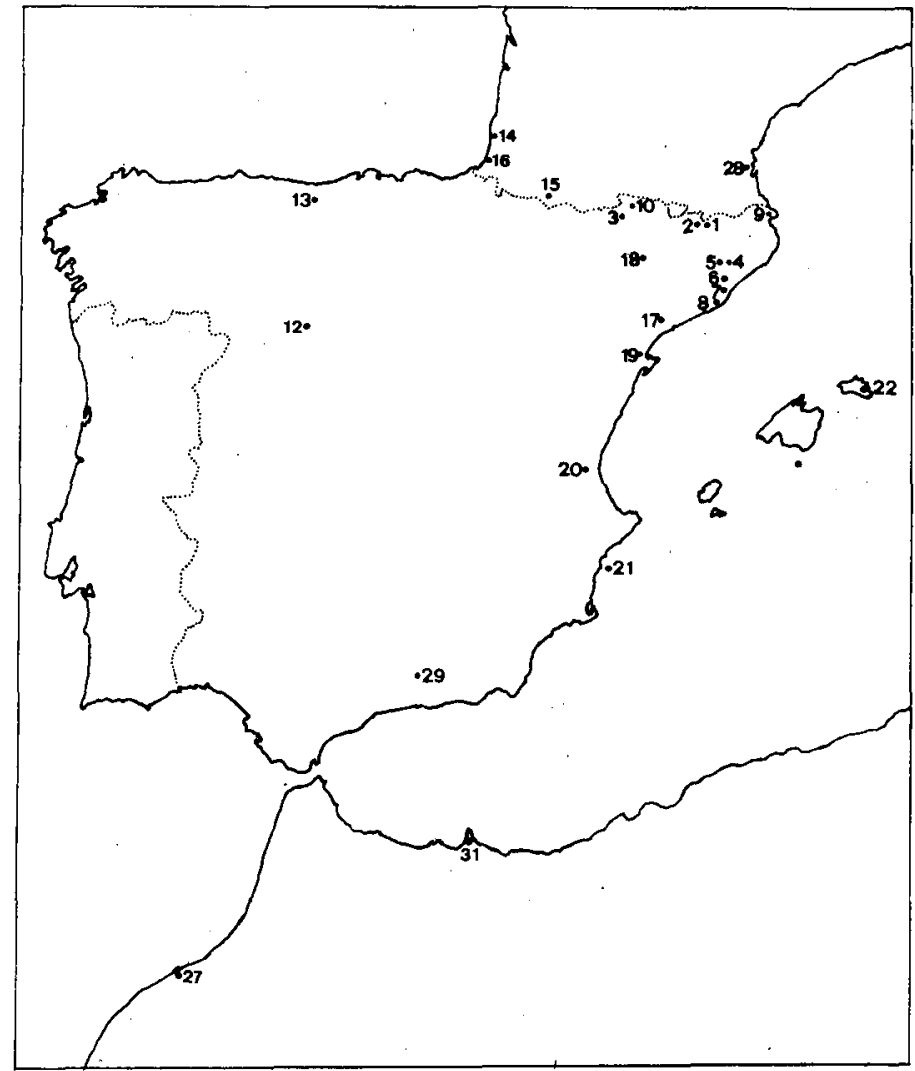

1) Campellas (T. sinuatocollis); 2) Planolas (T. sinuatocollis and T. tenebricosa); 3) Vall de Llauset (T. Indet. sp. and T. tenebricosa); 4) Collformic; 5) Collsuspina (T. monserratenals); 6) La Garriga (T. catalaunenals); 7 Tibidabo; 8) Garraf; 9) S. Pere de Roda (T. affinis); 10) Port de la Bonaigua (T. rectlcollis and $T$. strangulata); 12) Villanubla (T. perezl); 13) Pto. dé Aliva (T. geniculata); 14) Ondres-Plage (T. martima); 15) Gourette (T. montlcola); 16) Cap S. Martin (T. cyanescens); 17) Alió; 18) Port d'Ager; 19) Aldea; 20) Paterna (T. tallax); 21) Isla de Tabarca (T. Intermedia and T. espagnoli); 22) Mahón (T. balearlca); 27) El-Jadida (T. ventricosa); 28) Canet (T. Intersttialls); 29) Veleta (T. insparsa and T. lugens); 31) Melilla (T. rugosa). 
FIG. 2

Measurements performed in the sampled Timercha. P.m.w. = Pronotal maximum width; P.b.w. = Pronotal basis width; P.I. = Pronotal length; E.I. = Elytral length; E.w. = Elytral width; pt.t. = protarsal thickness; mt.t. = mesotarsal thickness; mtt.t. = metatarsal thickness.

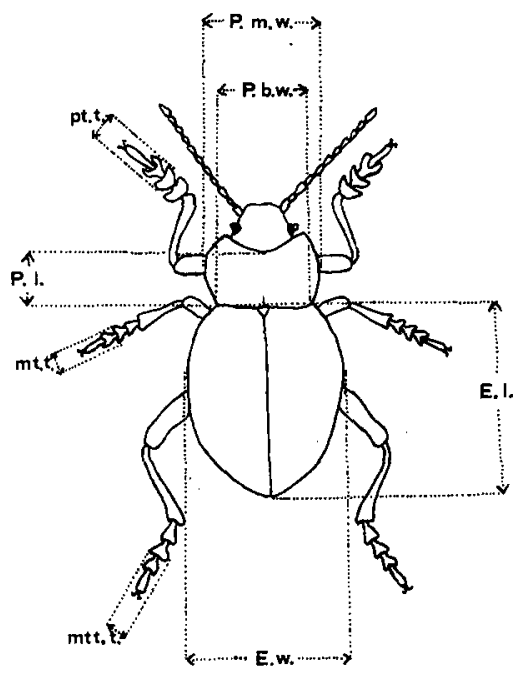


quoted by current systematists as a way to discriminate between taxa. Nevertheless, current systematics of Timarcha make use of other characters as for example mesosternum shape and pounctuation, which can not be easily homologated to our quantitative measurements.

The statistical analysis applied in this paper has been developed in three steps (Cuadras, 1972): 1) The homogeneity test of Barttlet to compare variance-covariance matrices of the sampled populations. This test was not significant. 2) Comparison of the population by Multivariate Analysis of the variance (that is considering all the biometric measurements at the same time) calculating the verosimility ratio which was transformed by asindotic approximation (Rao, 1965) in a $F$ of Fisher-Snedecor. The result was to detect great significant differences between populations in each sex. 3) The Canonical Analysis of populations to represent them with a minimum loss of information concerning to the Mahalanobis distance (Rao, 1948; 1952). 4) The two first autovectors of $\sum$ (covariability * «between» population with regard to $\Sigma$ (covariability «within» populations) were projected in this analysis. 5) The calculation of the $90 \%$ confidence interval for the center of each population. In this paper we have not used the approximative computation of radiud given by Seal (1964) but the error of the estimation of the $\sum$ matrix (common for the populations). The calculated radius for the $i$-population is $R_{\alpha}^{2} / \sqrt{n_{j}}$ being $R_{\propto}^{2}=F_{\alpha}(n-k) \cdot p /(n-k-p+1), .1-\alpha$ the confidence interval probability, $n$ the sum of the $k n, n$ the size of the i-population, and $P\left(F>F_{\alpha}\right)=\propto$ where $F$ follows a distribution of Fisher-Snedecor, with $p$ and $(n-k-p+1)$ as degrees of freedom (Cuadras, 1974 a; 1974 b).

\section{RESULTS}

We have developed two analysis for the whole population samples concerning each sex, which are graphically represented in figs. 3 and 4 . A bidimensional representation has been chosen since the first two canonical axes provided a high degree of discrimination (about $84 \%$ of the total variation between populations).

By comparing figs. 3 and 4 it becomes apparent that the discrimination between populations of males is clearer than between those of females because of the number of variables measured, being eight for males and five for females. However, the relative position of each sample is quite similar in both sexes with the exception of that of T. lugens ( $\left.n .^{\circ} 30\right)$ due to its remarkable sexual dimorphism. 
FIG. 3

Canonical Analysis of the male populations in Timarcha

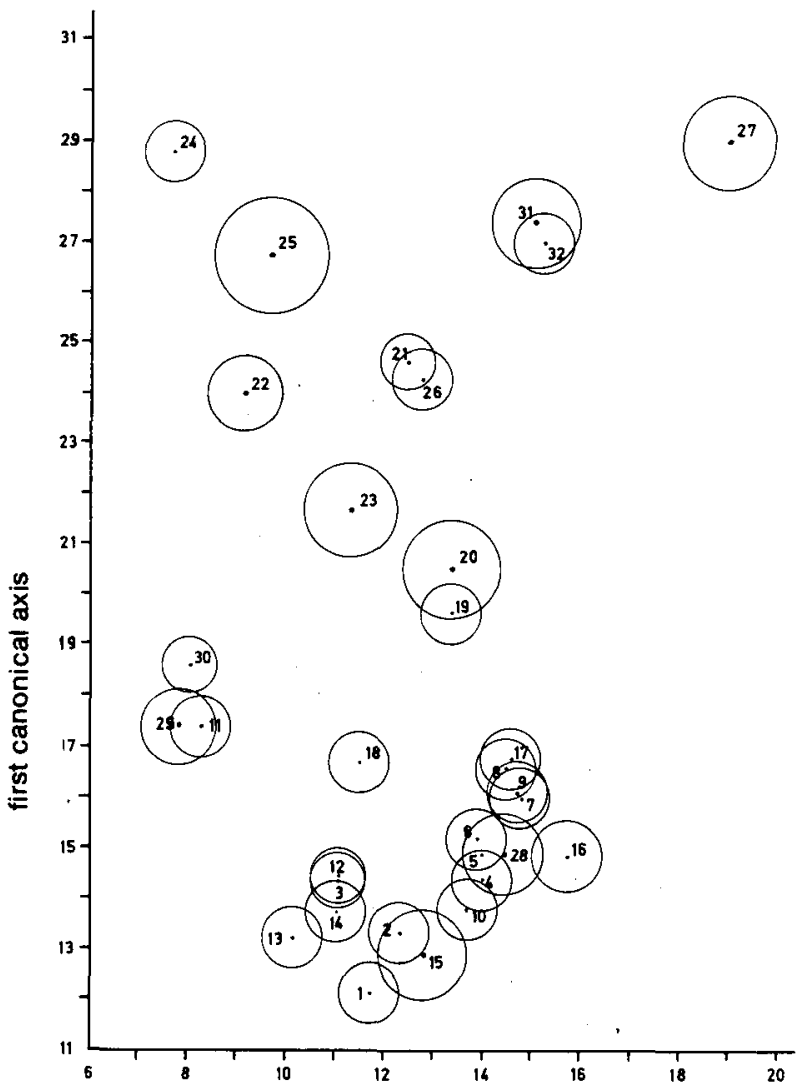

second canonical axis

$8 d 32$ 
FIG. 4

Canonical Analysis of the female populations in Timarcha.

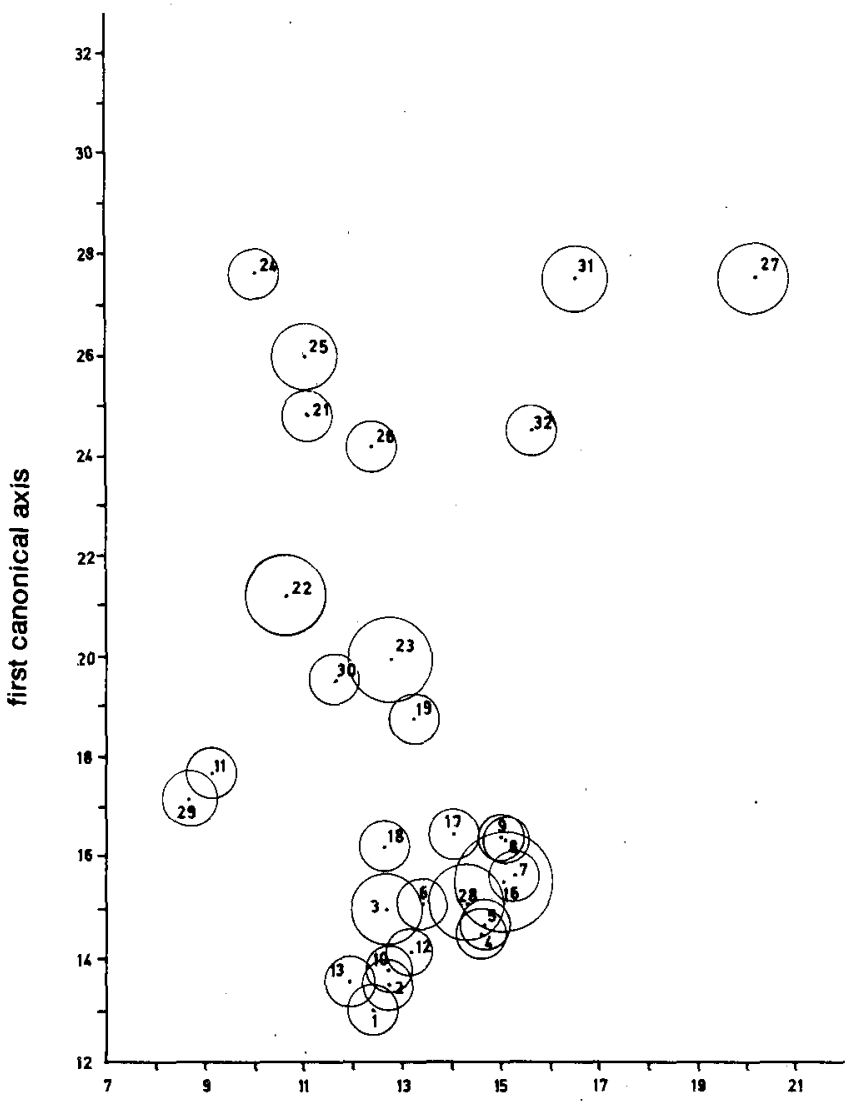

second canonical axis 
FIG. 5

Restricted Canonical Analysis of the male samples of closely related Timarcha plus $T$. strangulata population.

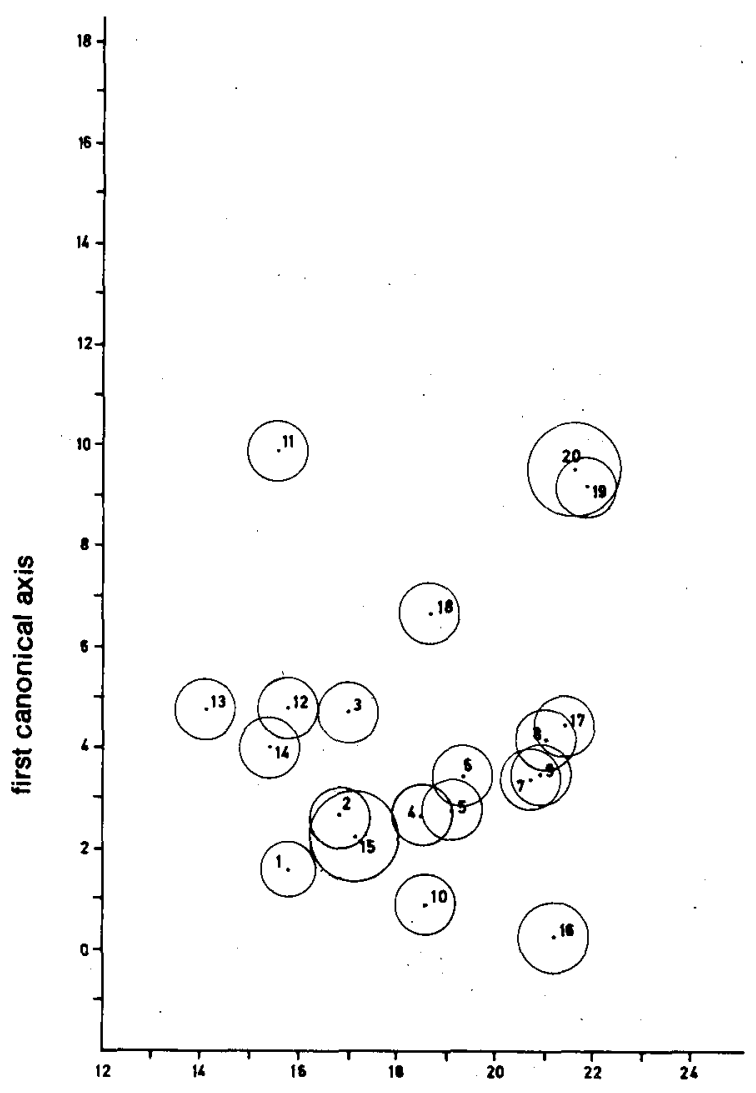

second canonical axis 
FIG. 6

Restricted Canonical Analysis of the female samples of closely related TImarcha plus T. strangulata population.

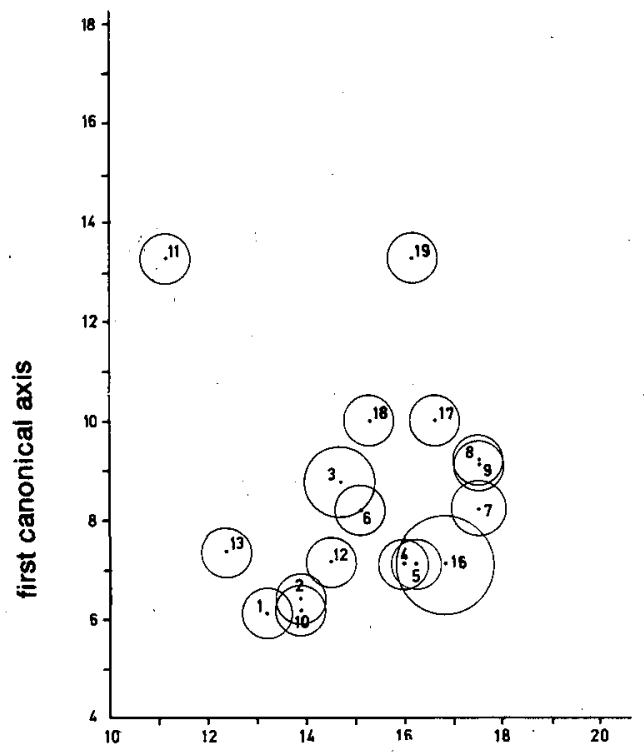

second canonical axis 
Both analysis show a cluster of samples with a considerable overlapping. These samples, plotted at the lower part of the graphs, contain most taxa of Timarcha having small size. The other samples are clearly separated from the previous group though a few of them are also overlapping (see fig. 3), like those of $T$. strangulata and $T$. insparsa (nos. 11 and 29, respectively), T. intermedia and $T$. espanoli (nos. 21 and 26, respectively), and $T$. rugosa and $T$. pimelioides (nos. 31 and 32, respectively).

A very striking fact is that some male samples of the same «species», like those of $T$. fallax (nos. 17, 18, 19 and 20), are more differentiated from each other than the samples classified into separated «species». Thus, the $T$. fallax population from Alio (no. 17) closely resembles that of $T$. affinis from Garraf (no. 8), but also to those of the other $T$. affinis populations (nos. 7 and 9). This situation is not so marked in the female analysis (see fig. 4). On the other hand, other samples of the same "species», like those of $T$. sinuatocollis (nos. 1 and 2) or $T$. affinis (nos. 7, 8 and 9) are plotted in neighbouring points in both analyses.

A group of four male samples corresponding to $T$. indet. sp. (no. 3), T. perezi (no. 12), T. geniculata (no. 13) and T. maritima (no. 14), are slightly isolated from the main cluster. This fact is accounted for by a difference in the tarsal thickness with regard to the remainder taxa of the main cluster. The antero-posterior decrease in the tarsal thickness is more accentuated from the 1st. to the 2nd. leg than from the latter to the 3rd., while it is roughly uniform in the remaining taxa of 'his cluster. Also, the more western population of $T$. fallax, that of Port d'Ager (no. 18), shows a similar characteristic (see fig. 3).

A more restricted analysis was also undertaken with only the samples of Timarcha pertaining to the previous main cluster and the sample of $T$. strangulata (no. 11). This latter species has also small size but it is very clearly separated from the other taxa by some morphological traits and other aspects of systematic value. The results obtained in both analyses parallels those previously described, though the discrimination among populations was better than before. The $T$. strangulata sample is perfectly isolated in both graphs (see fig. 5 and 6) from any other taxa while the remaining «species》 show at least some degree of overlapping.

\section{DISCUSSION}

We realize that the biometric methods, like the present analysis, should not be considered as corner-stones in systematic and phylogenetic studies. They are only helpful instruments which can 
clarify multiple instances of taxonomic problems, but it is truly advisable to base a systematic or evolutionary statement on more than just a purely biometrical criteria. Therefore, in this paper we shall discuss our results obtained by the Canonical Analysis with any other tool providing useful information about the taxonomic rank and species interrelationships in Timarcha.

The main cluster of population samples include those Timarcha of similar morphology though there can be substantial differences between these extreme forms. Since they constitute a cluster with a clear overlapping in both biometric and morphologic characters, their caryotypes are also very similar or indistinguishable, and this strong similarity is likewise supported by some biochemical aspects (Petitpierre, 1970; 1973 and 1976), therefore it seems reasonable to interpret them as a grouping of interrelated clines. A similar conclusion has also been recently reported by Minelli and Vitorelli (1976) on the various taxa enclosed in the T. tenebricosa grouping of Bechyné (1948), though the specific identity between $T$. nicaensis and $T$. tenebricosa does not seem completely claryfied yet.

However, it should be pointed out in our analysis that not all taxa included in this cluster of small Timarcha (we previously called $\& T$. goettingensis complex》) have reached the same evolutionary level. It seems possible that some taxa could have acquired many of the properties of a full species, but since most of them are largely allopatrie, only by several laboratory proofs will the degree of intersterility between each taxa be finally ascertained.

It seems likely that several evolutive branches have been originated from this cluster. The morphologic specialization is generally accompained by changes in the caryotypes by frequert increases in chromosome number (Petitpierre, 1970 a; 1976). A very clear branch is that constituted by the species having a bifurcated mesosternum, that is some species distributed in southern Spain principally, which seems to be directly derived from the more evolved T. fallax populations (nos. 18, 19 and 20). These southern species could be biometrically separated in two classes, one with $T$. insparsa (no. 29) and T. lugens (no. 30) and the other with T. intermedia (no. 21) and T. balearica (no. 22). Other evolutionary branches are that of T. nicaensis (no. 23) and T. tenebricosa (nos. 24 and 25), and that of the basically North African species with $T$. espanoli (no. 26), $T$. rugosa (no. 31), T. pimelioides (nc. 32) and T. ventricosa (no. 27), (see figs. 3 and 4 ).

Some species show a strong resemblance in our analyses (figs. 3 and 4). For example, T. strangulata (no. 11) and T. insparsa (no. 29) are largely overlapping in both male and female analyses. They are 
species distributed in similar habitats of high mountains, in the Pyrenees and in the Sierra Nevada, respectively. Moreover, this biometric convergence does not imply close interrelationship since they differ clearly in the mesosternum shape and male genitalia, and possess very distinct caryotypes (Petitpierre, 1970a; 1970b; 1976). An analogous resemblance but only in the male analysis (fig. 3 ), is shown in the two species of Tabarca (Alicante), T. intermedia) (no. 21) and $T$. espanoli (no. 26), and in T. rugosa (no. 31) and T. pimelioides (no. 32). Here again, there are striking morphologic differences in the first pair of species and quite appreciable ones in the second pair, and also a diversity in chromosome numbers (Petitpierre, 1970; 1976). These examples clearly indicate the advantages of taking into account other classes of systematic tools than the biometrics alone.

It can be argued that the fact of considering only one population sample for each taxon is a sophisticated mode of dealing with the typological species concept. However, it should by remembered that populations are natural evolutionary groups and not mere individuals more or less arbitrarily chosen as types. The sampled taxa of Timarcha have been analyzed in some cases by studying more than one population per taxon, and not only by this method of statistical analysis. Therefore, when there is a good agreement between biometric results and any aspect throwing light on genetic homology, the value of these results is enhanced and can only be questioned through a similar wide approach to the taxa interrelationships in Timarcha.

\section{CONCLUSIONS}

The results obtained by using the Canonical Analysis to 32 population samples pertaining to 24 taxa, that is 14 groups of Bechyné (1948), provide good evidence of the taxonomic and evolutionary status of several taxa in Timarcha. The biometric data are interpreted altogether with morphological systematics and caryology principally. In general, we have found a good agreement between biometrics and the other aspects with a few exceptions only. A very close biometric interrelationship has been detected between a cluster of taxa related to $T$. goettingensis. This cluster comprise the ancient Bechyné's groupings of: $T$. goettingensis, $T$. monticola, $T$. recticollis, $T$. fallax, T. geniculata and $T$. perezi. Since all these taxa show a striking genetic homogeneity and a gradual variation in the measured traits, it seems evident that they could not constitute independent species. Several interrelated clines best account for this situation though some isolated taxa could possibly exhibit a certain degree of sexual intersterility. 
The remaining species not included in this cluster are clearly separated but have also probably derived from it in various evolutive branches. This biometric analysis also demonstrates a few cases of convergence between species without a close genetic homology.

\section{ACKNOWLEDGEMENTS}

We are greatly indebted to the following people for their valuable contributions in compiling this paper. Among them Prof. A. Prevosti who first suggested to apply this statistical method, Mr. E. Durall who helped us many times in our collection trips, and Dr. G. Tiberghien and Mr. A. Pardo who provided the French populations and the $T$. rugosa sample, respectively.

\section{RESUMEN}

Los resultados obtenidos mediante el Análisis Canónico en 32 muestras poblacionales pertenecientes a 24 taxones, que corresponden a 14 grupos de Bechyné (1948), proporcionan pruebas acerca del estado taxonómico y evolutivo en múltiples taxones de Timarcha. Los datos biométricos se interpretan principalmente junto a los de la sistemática morfológica y de la cariología. En general, se ha demostrado concordancia entre la biometría y los otros aspectos, excepto en algunos casos. Se detecta un acentuado parentesco biométrico entre el conjunto de taxones relacionados con $T$. goettingensis. Este conjunto comprende los antiguos grupos de Bechyné: T. goettingensis, $T$. monticola, $T$. recticollis, $T$. fallax, $T$. geniculata y $T$. perezi. Como todos estos taxones manifiestan una fuerte homogeneidad genética y una variación gradual en los caracteres medidos, parece claro que no pueden ser ospecies independientes. Esta situación se explica adecuadamente considerando varias clinas interrelacionadas, aunque algunos taxones aislados pueden mostrar posiblemente un cierto grado de interesterilidad sexual.

Las restantes especies no incluidas en este conjunto se separan con claridad pero a su vez derivan probablemente de él en varias líneas filéticas. Este análisis biométrico demuestra también algunos ejemplos de convergencia entre especies sin una homología genética estrecha. 


\section{REFERENCES}

BECHYNE, J. - 1948. Contribution à la connaissance du genre Timarcha Latr. 12. Etudes phylogénétiques et zoogéographiques (Col. Phyt. Chrys.). Sbor Nar. Mus. Praze, IV B: 1-62.

CHEN, S. H. - 1934. Sur la position systématique du genre TImarcha Latr. Bull. Soc. Ent. France, 39: 35-38.

CUADRAS, C. M. - 1972. El Análisis Canónico y su aplicación en Geología. Acta Geológica Hisp. Barcelona. 7: 22-25.

CUADRAS, C. M. - 1974. a. Análisis Estadístico Multivariante y Representación Canónica de Funciones Estimables. Secretariado de Publ. de la Univ. de Barcelona, 23 pg. Ph. D. Summary.

CUADRAS, C. M. - 1974. b. Análisis Discriminante de Funciones Paramétricas Estimables. Trab. Estadistica Inv. Oper. Madrid, 25: 3-31.

FAIRMAIRE, L. - 1884. Liste complèmentaire des espèces du genre Timarcha. An. Hist. Nat., Madrid, 13: 75-112.

FAIRMAIRE, L. and ALLARD, D. - 1873. Revisión du genre TImarcha. Ann. Soc. Ent. France, 3: 143-202.

IABLOKOFF - KHNZORIAN, S. M. - 1966. Considerations sur l'édéage des Chryeomelldae et son importance phylogénique. L'Entomologiste, 22: 115-138.

JEANNE, C. - 1965. Révision des espèces françaises du genre Timarcha Latr. (Col. Chryeomellda0). Act. Soc. Linn. Bordeaux, 102 A: 1-25.

JOLIVET, P. - 1948. Introduction à la biologie des TImarcha (Col. Chrysomelldae). Misc. Ent. 45: 1-32.

KOCHER, L. - 1951. Notes sur les Timarcha marocaines (Col. Chrysomelidae). Contribution-à l'étude systématique du genre. Bull. Soc. Sci. Nat. Phys. Maroc, 31: 313-332.

KOCHER, L. - 1956. Observations complémentaires sur sur les Timarcha marocaines (Col. Chrysomelldae). Bull. Soc. Sci. Nat. Phys. Maroc, 36: 125-137.

LOUIS, J. and LEFEBVRE, J. - 1971. Les races d'abeilles (A. Mellifica L.) I. Détermination par l'Analyse Canonique, (étude prémilinaire). Rev. Biomét. Praximét., 12: 1-41.

MAYR, E. - 1963. Animal species and evolution. Harvard Univ. Press, Cambridge (Mass.), $797 \mathrm{pp}$.

MAYR, E. - 1969. Principles of Systematic Zoology. Mc Graw Hill, New York, 428 pp.

MINELLI, A. and VITORELLI, S.-(1976). II Rassenkreis TImarcha tenebricosa F. (Coleoptera Chrysomelidae). Boll. Mus. Civ. Stor. Nat. Verona, 3: 1-33.

PETITPIERRE, E. -1970 . a. Cytotaxonomy and evolution of Timarcha Latr. (Col. Chrysomelldae). Genét. Ibér. 22: 67-120.

PETITPIERRE, E. -1970 . b. Variaciones morfológicas y de la genitalia en las TImarcha Latr. (Col. Chrysomelldae). Publ. Inst. Biol. Apl. Barcelona, 48: 5-16.

PETITPIERRE, E. - 1973. Estudios sistemáticos, citogenéticos y evolutivos sobre el género Timarcha Latr. (Col. Chrysomelidae). Secretariado de Publ. Univ. Barcelona. Ph. D. Summary. 
PETITPIERRE, E. -(1976). Further cytotaxonomical and evolutionary studies on the genus Timarcha Latr. (Col. Chysomelldae). Genet. Iber., 28: 57-81.

PRUNUS, G. and LEFEBVRE, J. - 1971. L'analyse canonique appliquée à l'étude de la systématique évolutive chez l'Isopode Jaera (albifrons) albifrons Forsman. Arch. Zool. Exp. Gén., 112: 793-804.

RAO, C. R. -1948 . The utilization of Multiple Measurements in Problems of Biological Classification. J. Roy. Stat. Soc., B 10: 159-203.

RAO, C. R. - 1952. Advanced Statistical Methods in Biometric Research. J. Wiley, New York.

RAO, C. R. - (1965). Linear Statistical Analysis and its applications. J. Wiley, New York.

ROSTRON, J. - 1972. A multivariate statistical study of skull measurements of five taxa of gazelles. Biol. J. Linn. Soc., 4: 1-14

SEAL, H. L. - 1964. Multivariate statistical analysis for Biologists. Methuen, London, $207 \mathrm{pp}$.

STOCKMANN, R. - 1966. Etude de la variabilité de quelques espèces françaises du genre Timarcha Latreille (Col. Chrysomelldae). Ann. Soc. Ent. France. (N.S.), 2: 105-126. 